\title{
DETERMINATION OF WORK INDEX OF GRAPHITE FROM SAMAN- BURKONO (NIGERIA) USING MODIFIED BOND'S METHOD
}

\author{
M. O. Adeoti1, ${ }^{*}$, O. A. Dahunsi ${ }^{2}$, 0. O. Awopetu ${ }^{3}$, F. O. Aramide ${ }^{4}$, 0. 0. Alabi ${ }^{5}$, \\ O. T. Johnson ${ }^{6}$ and A. S. AbdulKareem ${ }^{7}$ \\ 1, Department of Mechanical Engineering, Federal Polytechnic, Bida, Niger State, Nigeria \\ 2, Dept. OF MeChanical Engineering, Federal University of TeChNology, AkURe, Ondo State, NIGERIA \\ 3, Dept. of Industrial \& Production Engr'G, Fed. Univ. of TeChnology, AKuRE, ONdo STATE, NIGERIA \\ 4, 5, Dept. Of Metallurgical\&Materials Engr'G, Fed. Univ. OF TeChnology, AkURe, Ondo State, Nigeria \\ 6, Department of Mining and Metallurgical Engineering, NAMUndjembo Mengela, OngWediva, NAMIBIA \\ 7, Dept. of Chemical Engineering, Federal University of TeChnology, MinNa, Niger State, NIGERIA \\ E-mail addresses: 1 lymath2015@gmail.com 2 tundedahunsi@gmail.com, \\ 3 olayinka.awopetu@gmail.com, ${ }^{4}$ foaramide@futa.edu.ng, 5 oladunni69alabi@yahoo.com, \\ 6ohnson.gbenga@gmail.com, 7 kasaka2003@gmail.com
}

\begin{abstract}
This report covers the work index determination of Saman-Burkono graphite. The test sample was obtained from Saman-Burkono in Ningi Local Government Area of Bauchi state, while reference material (coal) was sourced from Okaba coal mine, Ankpa Local Government Area of Kogi State. A known weight of graphite sample and coal were crushed, pulverized and ground using the laboratory milling machine. The two samples were grinded with two cells of diameter $3.5 \mathrm{~cm}$ and $222 \mathrm{~g}$ weight. The analysis of the feed size fort the two samples was found graphically to be $180 \mu \mathrm{m}$

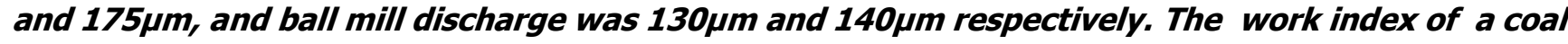
as reference material was $7.65 \mathrm{kWh} /$ short ton, this was used to calculate the work index of the graphite which was found to be $11.047 \mathrm{kWh} / \mathrm{short}$ ton, being the required energy to comminute one ton of graphite.
\end{abstract}

Keywords: Comminution, Graphite, Saman-Burkono, Nigeria, Modified Bonds method

\section{INTRODUCTION}

The insufficiency of energy resources in this present decade has led to the proper analysis of the energy requirements for use in engineering processes. One important aspect of the mineral industry is the comminution which invariably becomes the highest consumer of energy. Napier-Munn [1] stated that 30 50 per cent of the total plant power consumption for mineral processing plants and up to 70 per cent for hard ores is attributed to comminution. Comminution in the mineral processing plant is the sequence of crushing and grinding process, it is a process in which solid material are reduced in size, Crushing is a process whereby the particle size of run-off-mine ore is reduced to such a level that grinding can be carried out until the mineral and gangues are substantially produced as separated particles $[2,3]$. The grindability parameter which expresses the resistance of the material to crushing and grinding is known as Work index., numerically, it is the kilowatt hour per short ton required to reduce the material from theoretically infinite size to $80 \%$ passing 100 micron [3], work index determination using modified Bond's method can be compared to the method used by Berry and Bruce [4]. In this method, it requires the use of a reference ore of known grindability. Grindability can be defined as the ease with which materials can be broken into smaller particle sizes and the data obtained from these tests are used to calculate the required energy and grinding efficiency [5]. 
Determination of the required energy to effect rockbreakage is of fundamental importance in process design and which is achieved through work index. It was observed by Whittles that about 1.5 per cent of the annual electrical energy production in the United States of America is used in comminuting processes in the minerals industry [6] . Graphite is a crystalline and an allotropes of carbon that occurs as mineral, they can be used in many ways because of its resistance to high temperature, corrosive chemicals and its nonwettedness.

Graphite materials are good conductivity of heat and electricity with good refractory properties. The usefulness of graphite is dependent largely upon its types, the flake type is found to possess extremely low resistivity decreasing with increase in flaky particles; it finds a large use in the manufacture of carbon electrodes, plates and brushes required in the electrical industry and dry cell batteries. In the manufacture of plates and brushes, however, flake graphite has been substituted to some extent by synthetic amorphous, crystalline graphite and acetylene black. Graphite electrodes serve to give conductivity to the mass of manganese dioxide used in dry batteries. The manufacture of crucibles is served best by flake graphite, although crystalline graphite is also used [7]. Graphite crucibles are manufactured by pressing a mixture of graphite, clay and sand, fixing the pressed articles at a high temperature. They are used for melting non- ferrous metals, especially brass and aluminum. Coarse-grained flake graphite from Malagasy is regarded as standard for crucible manufacture [8].

Therefore, energy required to grind one tonne of an ore from a given feed size to a specified product size is a material property that needs to be determined for different mineral deposits. This work aimed at the determination of work index of Saman-Burkono graphite ore. The study used Okaba coal as a reference material with a comparative method to determine the Bond's work index.

\section{MATERIALS AND METHODS}

\subsection{Sample Collection}

The graphite sample utilized in this research was obtained from the main bulk at Saman-Burkono graphite deposit in Ningi Local Government Area of Bauchi State, Nigeria, about 20 Kilometers away from Bauchi along Kano road with a coordinate of $11^{\circ} 11^{\prime}$ $0^{\prime \prime} \mathrm{N}, 9^{\circ} 45^{\prime} 0^{\prime \prime} \mathrm{E}$, and has an area coverage of about10 hectares (100,000 square meters) of land, while the reference material was sourced from Okaba coal mine, Okaba town in Kogi State, using random sampling method. The samples were collected in lumps size at different lode (Bulk deposit) locations of 10meters apart and 30meters depth within the deposit

\subsection{Sample Preparation}

The graphite samples were crushed to size reduced from boulders to $10 \mathrm{~mm}$ size, this was further ground to pulverized size. Part of the pulverized sample was weighed for sieve analysis and part was weighed for ball mill operation for further size reduction (grinding).

\subsection{Procedure for the Determination of Work Index Using Modified Bond's Method}

The modified Bond's method for determining work index of an ore involves the use of reference ore of known grindability. Experimental procedures were as follows:

1. $100 \mathrm{~g}$ each of ore of graphite and coal samples were crushed and pulverized.

2. An identical weight of both samples were taken and sized by sieving into a number of size fractions using automatic sieve shaker for 10 minutes.

3. Each size fraction of the test and reference ores were weighed and the values noted as the "feed".

4. The "feed" test and reference ore were each gathered together and introduced into laboratory ball mill machine and ground for one hour.

5. The test and the reference ores from the laboratory ball mill machine were sized and each sieve fraction was weighed and the value noted as "product" or "discharge."

6. Sieve Size Analysis: The ground samples were sieved into the following sieve size fractions; 180 $\mu \mathrm{m}, 125 \mu \mathrm{m}, 90 \mu \mathrm{m}, 63 \mu \mathrm{m}$ and $45 \mu \mathrm{m}$ and these were arranged using root two $(\sqrt{ } 2)$ method and were sieved for 10 minutes using automatic rotap sieve shaker.

\subsection{Calculations of Result}

From Table 1:

by proportion, if $125 \mu \mathrm{m}=67.54 \%$, then $\mathrm{X}=80 \%$ Using Gaudin Schuman Expressions

$P(X)=100(X / K)^{x}$ 
$X=\frac{\log P(X 2-P(X 1)}{\log (X 2)-\log (X 1)}$

Size $_{2}=\frac{(\text { Percentage Passing size } 2) 2}{(\text { percentage Passing Size } 1) 2} \times$ Size $_{1}$

$\mathrm{X} \mu \mathrm{m}=\left(\frac{80 / 100}{67.54 / 100}\right)$ square $\mathrm{X} 125$

$=\left(\frac{0.8}{0.68}\right)$ squre $X 125=1.38 \times 125=173.01 \mu \mathrm{m}$

From Table 2:

$125 \mu \mathrm{m}=75.04 \%, \mathrm{X} \mu \mathrm{m}=80 \%$

$=\left(\frac{80 / 100}{75.04 / 100}\right)$ square $X 125=142.07 \mu \mathrm{m}$

From Table 3.

If $125 \mu \mathrm{m}=78.74$, Then $\mathrm{X}=80 \%$

$X \mu \mathrm{m}=\left(\frac{80 / 100}{78.74 / 100}\right)^{2} \times 125=\left(\frac{0.8}{0.7874}\right)^{2} \times 125=129.03$

$\mu \mathrm{m}$

From Table 4

If $180=80.2 \%, X \mu m=80 \%$

$=\left(\frac{\frac{80}{100}}{\frac{80.2}{100}}\right)^{2} \times 180=\left(\frac{0.8}{0.82}\right) \times 180=171.33 \mu \mathrm{m}$

If $r$ is the reference ore and $t$ is the ore under test.

From bond's equation: Then;

$$
\begin{gathered}
W=W_{i t}=W_{i r}=\left[\frac{10}{\sqrt{P}}-\frac{10}{\sqrt{F}}\right] \\
W_{i t}=W_{i r}=\frac{\frac{10}{\sqrt{P_{r}}}-\frac{10}{\sqrt{F_{r}}}}{\frac{10}{\sqrt{P_{t}}}-\frac{10}{\sqrt{F_{t}}}}
\end{gathered}
$$

where: $\mathrm{W}_{\mathrm{ir}}=$ work index of the reference ore
$\mathrm{W}_{\mathrm{it}}=$ work index of the test ore

$\mathrm{Pr}_{\mathrm{r}}=$ the diameter of the Okaba ore through which $80 \%$ of the product passes through $100 \mu \mathrm{m}$

$\mathrm{P}_{\mathrm{t}}=$ the diameter of the test ore through which $80 \%$ of the product passes through $100 \mu \mathrm{m}$

$\mathrm{F}_{\mathrm{r}}=$ the diameter of the reference ore through which $80 \%$ of the feed passes through $100 \mu \mathrm{m}$

$\mathrm{F}_{\mathrm{t}}=$ the diameter of the test ore through which $80 \%$ of the feed passes through $100 \mu \mathrm{m}$

$\mathrm{W}_{\mathrm{r}}=$ work input in kilowatt hour per short ton for the reference ore.

$\mathrm{W}_{\mathrm{t}}=$ work input in kilowatt hour per short ton for the test ore.

$\mathrm{F}_{\mathrm{t}} \quad=\quad 173.01 \mu \mathrm{m}$

$\mathrm{P}_{\mathrm{t}} \quad=\quad 142.07 \mu \mathrm{m}$

Fr $\quad=\quad 171.3 \mu \mathrm{m}$

$\operatorname{Pr} \quad=\quad 130 \mu \mathrm{m}$

Substituting the values into equation 2 .

$W_{i t}=W_{i r}=\frac{\frac{10}{\sqrt{129.8}}-\frac{10}{\sqrt{171.3}}}{\frac{10}{\sqrt{142.07}}-\frac{10}{\sqrt{173.01}}}=7.65 \times 1.444=11.047$

$\mathrm{kWh} /$ ton

\section{RESULTS AND DISCUSSIONS}

\subsection{Results}

Results of experiments carried out are presented in

Tables $1-4$.

Table 1: Result of sieve size analysis of the "feed" test material (Graphite).

\begin{tabular}{llllll}
\hline $\begin{array}{l}\text { Sieve size } \\
\text { Range }(\mu \mathrm{m})\end{array}$ & $\begin{array}{l}\text { Weight } \\
\text { retained }(\mathrm{g})\end{array}$ & $\begin{array}{l}\text { \% weight } \\
\text { retained }\end{array}$ & $\begin{array}{l}\text { Nominal } \\
\text { aperture }\end{array}$ & $\begin{array}{l}\text { Cumulative \% } \\
\text { Weight retained }\end{array}$ & $\begin{array}{l}\text { Cumulative \% } \\
\text { Weight passing }\end{array}$ \\
\hline+180 & 18.37 & 18.37 & 180 & 18.37 & 81.63 \\
$-180+125$ & 14.09 & 14.09 & 125 & 32.46 & 67.54 \\
$-125+90$ & 15.31 & 15.31 & 90 & 47.77 & 52.23 \\
$-90+63$ & 21.65 & 21.65 & 63 & 69.42 & 30.58 \\
$-63+45$ & 18.62 & 18.62 & 45 & 88.04 & 11.96 \\
-45 & 11.96 & 11.96 & - & 100 & 0.00 \\
\hline
\end{tabular}

Table 2: Result of sieve size analysis of the "product" test material (Graphite).

\begin{tabular}{cccccc}
\hline $\begin{array}{c}\text { Sieve size } \\
\text { Range }(\mu \mathrm{m})\end{array}$ & $\begin{array}{c}\text { Weight } \\
\text { retained } \\
(\mathrm{g})\end{array}$ & $\begin{array}{c}\text { \% weight } \\
\text { retained }\end{array}$ & $\begin{array}{c}\text { Nominal } \\
\text { aperture }\end{array}$ & $\begin{array}{c}\text { Cumulative } \\
\text { \%Weight } \\
\text { Retained }\end{array}$ & $\begin{array}{c}\text { Cumulative } \\
\text { \%Weight } \\
\text { passing }\end{array}$ \\
\hline+180 & 7.84 & 7.84 & 180 & 7.84 & 92.16 \\
$-180+125$ & 17.12 & 17.12 & 125 & 24.96 & 75.04 \\
$-125+90$ & 15.56 & 15.56 & 90 & 40.52 & 59.48 \\
$-90+63$ & 25.15 & 25.15 & 63 & 65.67 & 34.33 \\
$-63+45$ & 16.40 & 16.40 & 45 & 82.07 & 17.93 \\
-45 & 17.93 & 17.93 & - & 100 & 0.00 \\
\hline
\end{tabular}


Determination of Work IndeX of Graphite from SAman-Burkono (Nigeria) using Modified Bond's Method, M. O. Adeoti, et al

Table 3: Result of sieve size analysis of the feed reference material (Okaba Coal)

\begin{tabular}{llllll}
\hline $\begin{array}{c}\text { Sieve size } \\
\text { Range }(\mu \mathrm{m})\end{array}$ & $\begin{array}{c}\text { Weight } \\
\text { retained }(\mathrm{g})\end{array}$ & $\begin{array}{c}\text { \% weight } \\
\text { retained }\end{array}$ & $\begin{array}{c}\text { Nominal } \\
\text { aperture }\end{array}$ & $\begin{array}{c}\text { Cumulative \% } \\
\text { Weight retained }\end{array}$ & $\begin{array}{c}\text { Cumulative \% } \\
\text { Weight passing }\end{array}$ \\
\hline+180 & 19.80 & 19.80 & 180 & 19.80 & 80.20 \\
$-180+125$ & 18.80 & 18.80 & 125 & 38.60 & 61.40 \\
$-125+90$ & 11.50 & 11.50 & 90 & 50.10 & 49.90 \\
$-90+63$ & 07.80 & 07.80 & 63 & 57.90 & 42.10 \\
$-63+45$ & 01.60 & 01.60 & 45 & 59.50 & 40.50 \\
-45 & 40.50 & 40.50 & - & 100 & 0.00 \\
\hline
\end{tabular}

Table 4: Result of sieve size analysis of the "product" reference material (Okaba Coal)

\begin{tabular}{cccccc}
\hline $\begin{array}{c}\text { Sieve size } \\
\text { Range }(\mu \mathrm{m})\end{array}$ & $\begin{array}{c}\text { Weight } \\
\text { retained }(\mathrm{g})\end{array}$ & $\begin{array}{c}\% \text { weight } \\
\text { retained }\end{array}$ & $\begin{array}{c}\text { Nominal } \\
\text { aperture }\end{array}$ & $\begin{array}{c}\text { Cumulative \% } \\
\text { Weight retained }\end{array}$ & $\begin{array}{c}\text { Cumulative \% } \\
\text { Weight passing }\end{array}$ \\
\hline+180 & 06.00 & 06.00 & 180 & 06.00 & 94.00 \\
$-180+125$ & 15.26 & 15.26 & 125 & 21.26 & 78.74 \\
$-125+90$ & 20.03 & 20.03 & 90 & 41.29 & 58.71 \\
$-90+63$ & 23.40 & 23.40 & 63 & 64.69 & 35.31 \\
$-63+45$ & 11.77 & 11.77 & 45 & 76.46 & 23.54 \\
-45 & 23.54 & 23.54 & - & 100 & 0.00 \\
\hline
\end{tabular}

\section{DISCUSSIONS OF RESULTS}

Tables $1-4$ shows the results in tabular form, the results shows the particle size fractions of the graphite material and the coal as reference ore, show a normal distribution pattern, indicating that the particle size fractions responded to the theories of comminution. That is, the energy consumed in size reduction is proportional to the area of new surface produced [9]. The $80 \%$ passing is obtained to be $171.3 \mu \mathrm{m}$ and $129.8 \mu \mathrm{m}$ for the reference material (Feed \& Product) and $173.01 \mu \mathrm{m}, 142.07 \mu \mathrm{m}$ for the test ore respectively. This gave an average work index of the as-received Saman-Burkono graphite to be 11.047 $\mathrm{kWh} / \mathrm{ton}$. The computed work index is within work indices of other graphite mineral used as standard that fall between 1.75-45.03 kWh/ton sighted in the literatures $[1,10,11]$. The value obtained proved that $11.047 \mathrm{kWh} / \mathrm{hr}$. of energy is required to reduce one tonne of the as - received graphite ore sample from $80 \%$ passing sieve size $173.01 \mu \mathrm{m}$ to $80 \%$ passing sieve size of $142.07 \mu \mathrm{m}$. This ore is therefore by this result termed as ore "type $B$ " of Denver grindability curves $[9,10,13]$.

\section{CONCLUSION}

In conclusion, the determination of work index of Saman-Burkono graphite, Bauchi State, Nigeria was investigated using modified Bond's Energy method.
From the results of the experiments the work index was found to be $11.047 \mathrm{kWh} /$ ton; considering the economic implication it indicates that the cost of energy used to comminute one ton of the study ore to $80 \%$ passing 100 microns will cost $\$ 303.79 \mathrm{k}$ at a unit cost of $27.5 \mathrm{k}$ per energy- being a unit cost of power consumption by industries in Nigeria [12].This parameter is significant for use in the design of a process route for the beneficiation of the SamanBurkono graphite.

\section{REFERENCES}

[1] Napier-Munn, T. J., Morell, S., Morrison, R. D., and Kojovic, T. (1996): Mineral Comminution Circuits: Their Operation and Optimisation. JKMRC Monograph Series in Mining and Mineral Processing, 2 University of Queensland, Australia.

[2] Wills, B. A., and Napier-Munn, T. Y. (2006): Mineral Processing Technology, $3^{\text {rd }}$ Edition, Elsivier Publisher Limited, Burlington, U.S.A., pp 108-115.

[3] Magdalimovic, N. M. (1989): Calculation for Energy required for grinding in ball mill. International Journal of Mineral Processing, Vol 25, No. 2, pp 41-43

[4] Berry, T. F., \& Bruce, R. W. (1966): A Simple Method of Determining the Grindability of 
Ores. Canadian Mining Journal, Vol.8, No. 7, pp 63-65.

[5] Alabi, O. O., Shehu Y. A., Binta H., (2012): Determination of Bond Index of Wasagu Manganese Ore in Kebbi State, Nigeria. International Journal of Scientific and Engineering Research, Vol. 3, No. 10, pp $1-8$.

[6] Whittles, D. N., Kingman, S. W., \& Reddish, D. J. (2003): Application of numerical modelling for prediction of the influence of power density on microwave-assisted breakage. International Journal of Mineral Processing, Vol. 68, pp 71-91

[7] Andrews, P. R. A. (2010): Review of Developments in Casseterite Flotation in Respect of Physicochemical Considerations, Minerals, Materials and Industry, IMM London, pp 345- 347

[8] Broekaert, E. (2004): New Processes for Casseterite Ore Flotation in Mineral Processing and Extractive Metallurgy, ed. M. J. Jones and P. Gill, IMM, London, pp 453-458.

[9] Alabi, O. O., Yaro, S. A., Dungka, G. T., Asuke, F. and Dauda, E. T. (2015): Determination of workindex of Gyel - Bukuru columbite ore in Plateau State, Nigeria, Journal of Mineral and Materials Characterisation and Engineering, Vol. 3, pp 194 203.
[10] Thomas, D. G., Asuke, F. and Yaro, S. A. (2014): Determination of Some Conceptual Mineral Processing Parameters of Soba-Wanka Pyrochlore-Col Tan Mineral Ore Deposit. 2014 Nigeria Engineering Conference, Vol. 2, pp 32-41.

[11] Ministry of Mines and Steel Development (2012): Road Map for the Development of Solid Minerals and Metals Sector. Stack Holders Forum, Abuja, Vol. 3, pp 4-9.

[12] Thomas, D. G., Asuke, F., and Yaro, S. A. (2016): Determination of Work Index of Zarara Complex Ore Deposit, Kaduna. Nigerian Society of Mining Engineers (NSME) Conference, Abuja.

[13] Obassi E., Gundu, D.T. and Akindele U.M. (2015): Determination of Work index of Arufu lead ore, Nasarawa State, North-central, Nigeria, International Journal of Engineering and Science, Vol. 4, Issue 2, pp 10-14.

[14] Todorovic D, Trumic M., Andric L., Milosevic V., and Trumic Milan, (2016): A Quick method for Bond work index approximate value Determination, Physiochemical Problems of Mineral processing, Vol. 3, No.1, pp 321-332. www.minproc.pwr.wroc.pl/journal/ 